\title{
1. The global landscape of collective litigation
}

\section{Deborah R. Hensler}

\section{INTRODUCTION}

Over the past several decades, the class action-a representative legal procedure in which some person or organization comes forward to litigate on behalf of a group or group interest-has spread worldwide. Some form of representative collective litigation procedure is now recognized by more than three dozen national jurisdictions (see Table 1.1). The procedure goes by different formal names in different parts of the world-for example 'collective action', 'collective redress', 'popular action'-but is often referred to informally as a class action in recognition of its resemblance to the American class action. Although previously regarded strictly as a common law procedure, the class action has now been integrated into civil law regimes in Asia, Europe and South America, and 21 of the 25 largest economies in the world have adopted a class action procedure to date, most in the last 20 years. As a result of the 2013 European Union Recommendation on Collective Redress, ${ }^{1}$ more European countries can be expected to join this list in the near future.

Many jurisdictions provide for class actions by statute. In some jurisdictions that do not have such statutes but have Constitutions or statutes that grant collective rights-for example, for protection of consumers, the environment or national heritage-judges have permitted representative collective litigation to claim those rights. In the United States (US), federal and state rules of civil procedure provide for class actions.

1 Commission Recommendation of 11 June 2013 on common principles for injunctive and compensatory collective redress mechanisms in the member states concerning violations of rights granted under Union Law (2013/396/EU) available at http://eur-lex.europa.eu/legal-content/EN/TXT/?uri=OJ:JOL_2013_201_ R_NS0013. 
The spread of class actions globally is an example of what have come to be called 'legal transplants' (Watson, 1974). The term refers to a legal institution, doctrine, rule or practice that after arising in one country is adopted in one or more other countries (Graziadei, 2006). An extensive literature on legal transplants sees them as a sub-set of public policies that have diffused across jurisdictions, sometimes as a result of external pressure and sometimes in response to perceived domestic needs (Dobbins, Simmons \& Garrett, 2007).

To date, there has been no systematic analysis of the factors motivating the spread of class actions beyond the US, but one of the most important seems to be the increased frequency of mass claims. With the rise of multinational and national corporations whose success depends on their ability to market goods and services to vast populations, the chance of mass injuries resulting from negligence or violations of private contractual terms or public law or other unknown causes has increased markedly. Mineral resource extraction and distribution and electric power generation - all marks of a modern economy - have also been sources of mass injuries and environmental damage. Analysts have speculated that as societies modernize, popular expectations of redress in such instances increase, as events that were once viewed as chance occurrences or ordained by deities are increasingly attributed to human behaviors. Consistent with this observation, legal doctrine in many countries now holds private and public institutions accountable for violating legal standards-for example, by manufacturing and selling defective products, failing to accurately disclose financial information to shareholders, colluding on price with other manufacturers or service providers, and damaging the environment. Accountability is often although not always tied to a responsibility to redress losses. As a result of these economic, cultural and legal changes when many individuals or organizations suffer personal injury, property damage or financial harm allegedly as a result of another party's improper behavior, it is now common for a large number of similar claims ('mass claims') to appear (Hensler, 2013).

Typically designed to handle single claims on a case-by-case basis, neither private dispute resolution institutions nor public courts are well-equipped to handle a sudden deluge of claims arising from an untoward event or information disclosure. To many, the similarity of law and facts that characterizes mass claims suggests that some sort of group treatment might be attractive. The class action procedure is one such approach. Others include private and public administrative programs that permit quick processing of individual claims according to a wellspecified protocol; group litigation procedures; and ad hoc management strategies that identify certain aspects of claims that can be resolved on a 
Table 1.1 Countries that have adopted a class action procedure for one or more types of legal claims

\begin{tabular}{|c|c|c|c|c|}
\hline $\begin{array}{l}\text { NORTH } \\
\text { AMERICA }\end{array}$ & $\begin{array}{l}\text { CENTRAL \& } \\
\text { SOUTH } \\
\text { AMERICA }\end{array}$ & $\begin{array}{l}\text { EUROPE \& } \\
\text { THE } \\
\text { MIDDLE } \\
\text { EAST }\end{array}$ & AFRICA & $\begin{array}{l}\text { ASIA \& } \\
\text { AUSTRALASIA }\end{array}$ \\
\hline Canada & Argentina & Belgium & South Africa & Australia \\
\hline Mexico & Bolivia & Bulgaria & & China \\
\hline \multirow[t]{13}{*}{ United States } & Brazil & Denmark & & Indonesia \\
\hline & Chile & England & & Japan \\
\hline & Colombia & Finland & & South Korea \\
\hline & Costa Rica & France & & Taiwan \\
\hline & Ecuador & Israel & & Thailand \\
\hline & Panama & Italy & & \\
\hline & Peru & Lithuania & & \\
\hline & Uruguay & Netherlands & & \\
\hline & Venezuela & Norway & & \\
\hline & & Poland & & \\
\hline & & Portugal & & \\
\hline & & Spain & & \\
\hline & & Sweden & & \\
\hline
\end{tabular}

group-wide basis. What distinguishes all of these latter procedures from a class action is that they all preserve-at least as a formal matter-the ability of claimants to pursue redress on an individual basis and the ability of potential payers to contest their responsibility for such redress on an individual basis.

Administrative schemes adopted to resolve mass claims typically sort claims into groups-for example, by type of injury or amount of financial loss-and apply the same treatment to all the claims within each group, ignoring possible individual differences. This is sometimes termed a 'compensation matrix'. These types of schemes have been adopted by governments to forestall or minimize litigation and by private corporations, both on a voluntary basis and as a result of a negotiated settlement of lawsuits (Feinberg, 2012).

Group litigation procedures permit a judge or other dispute resolution official to apply decisions on common issues-for example, jurisdictional 
competence or admissibility of evidence - to all of the claims in a group while preserving final decisions on the merits for individual claim resolution. Sometimes the resolution of common issues leads to voluntary group settlements by the parties. England, Germany and the US are three national jurisdictions that have formally adopted such procedures (Hodges, 2001; Hensler, 2014).

Informal ad hoc strategies allow a judge or other dispute resolution officer to identify circumstantial aspects of claims that make group treatment advantageous without impairing claimants' ability to proceed individually. Often termed 'case management', this approach took hold in US courts more than two decades ago, in part in response to mass litigation, and was endorsed by English jurists in the late 1990s. Civil law judges have long had the authority to shape the course of civil lawsuits but many are said to be reluctant to engage in the close direction of lawsuits that is typical of managerial judges in the US and England.

In contrast to administrative programs, group litigation procedures and informal case management, in a class action the class members' interests are represented by one or a few individuals or organizations that they may have had no role in selecting. Typically, the class members' claims are not formally before the court (hence the term, 'absent parties' to apply to class members), but the decision of the court will significantly affect their claims. (In formal terms, the outcome is res judicata.) Because this is such a radical departure from modern legal norms, most jurisdictions that permit class actions specify the circumstances in which a class action may proceed, require a judge to 'certify' that the dispute fits these circumstances and require either that potential class members be notified that they can join the litigation if they wish or that they can decline to participate. Many jurisdictions' class action statutes or rules also include other provisions intended to protect the interests of class members, including their right to a fair adjudicatory process ('due process').

Although many recently legislated class action procedures were adopted to deal with instances of mass claims, there are other situations in which legislatures or judiciaries have deemed collective litigation appropriate. For example, many Latin American jurisdictions provide for class actions to protect indivisible collective interests (variously called 'diffuse' or 'popular' interests), such as environmental quality. Unlike class actions that aggregate individual claims for redress, these actions typically seek declaratory or injunctive relief, not monetary damages. In some instances, the indivisible interest is that of a specific group, for example, an indigenous community in the environs of resource extraction; in others, it is the public at large. The modern form of the US class 
action rule provides for both collective interest claims (although this term is rarely used in US procedural law) and aggregated monetary claims.

The class action statutes and rules adopted around the world in recent years differ in several important respects. In some jurisdictions, the rule is trans-substantive, meaning class actions may be pursued in virtually every circumstance in which an individual claim could be brought. For example, in Australia, Canada, the Netherlands and the US, investors may bring class actions for violation of securities law, businesses and consumers may bring class actions for violation of anti-trust (competition) statutes, consumers may bring class actions for violation of consumer protection statutes, and citizens may bring suits for violation of their constitutional rights. Israel's procedure is not trans-substantive but permits class actions for many causes of action, including, among others, consumer, securities, banking, antitrust, environmental, employment and discrimination claims.

In other jurisdictions, class actions may be used exclusively for consumer protection (for example, Belgium, France and Japan) or shareholder claims (for example, South Korea) or anti-trust (competition) claims (for example, the United Kingdom), or in more limited factspecific circumstances. Some jurisdictions first adopted a class action procedure to address a particular situation but then extended it to apply to other mass claim situations. For example, the Netherlands' collective settlement procedure (which permits claimants and defendants to jointly petition a court to approve a global 'opt-out' settlement that they have negotiated) was adopted initially to assist in a large-scale settlement of DES pharmaceutical product defect claims but has since been used to resolve securities, investment product and insolvency litigation. Israel enacted multiple statutes for different types of substantive claims that permitted class actions, before it adopted a more general class action statute.

Another important distinction among class action procedures is who has standing to represent the class. In common law jurisdictions with class action procedures, any class member may come forward to represent the class, provided that party meets certain requirements intended to assure that the representative will adequately represent the interests of all class members. In many civil law jurisdictions, standing is limited to one or a few associations that have been declared eligible to represent a class or to special purpose foundations established to bring the action. In a few jurisdictions, only a government official may bring certain types of class actions. In all EU member states, whether based on civil law or common law, standing is permitted for defined public and private entities. 
In some jurisdictions, everyone who meets the class definition must come forward and affirmatively state that they wish to be part of the action ('opt in') in order to realize its benefits. In other jurisdictions, everyone who meets the class definition is considered a class member unless they formally declare that they do not want to be part of the action ('opt out'). (In a few jurisdictions, the court may decide whether a class action should proceed on an opt-out or opt-in basis.) In both sorts of class actions, the outcome of the suit binds all of the class members, meaning that they are not free to individually litigate the issues that were decided (or settled) in the class litigation. In jurisdictions where standing to bring a collective action is limited to an association, the decision may formally bind only that association or that association's members.

Finally, in some jurisdictions, class actions may only deliver declaratory or injunctive relief (even when class members are seeking monetary compensation), while in others, class actions may yield declaratory or injunctive relief or money damages (or all three). In jurisdictions where class members cannot obtain monetary damages, if the court issues a declaratory judgment holding that the defendant has violated the law, class members seeking monetary redress must file individual follow-on lawsuits to pursue those claims.

Taken together, these (and other) provisions of class action procedures determine how often class action lawsuits will be filed, by whom and under what circumstances. However, class actions do not operate independently of other features of civil litigation regimes. Rules on how the costs of litigation are allocated between plaintiffs and defendants, and how lawyers may be paid have a significant impact on individuals' and organizations' willingness to serve as class representatives. Most jurisdictions other than the US impose a 'loser-pays' rule on all civil litigation including class actions (Hodges, Vogenauer and Tulibacka, 2010). In ordinary litigation this means that if plaintiffs lose they must pay the defendants' costs (and vice versa). This substantially increases the risk of litigating. In a class action, it is the representative plaintiff who bears the risk of adverse costs. In a jurisdiction that permits individual class members to serve as class representatives, there may be no class member who is willing to take this risk. But cost shifting does not only deter individual class members. In a jurisdiction that limits standing to associations and other non-profit organizations, there may be few that have the resources to take on this risk. Even public officials who have standing to bring class actions have to calculate the risk of proceeding against the background of budgetary constraints. In some jurisdictions, private or public funding mechanisms have emerged to mitigate the adverse cost risk for representative plaintiffs. 
Most class actions are more complex than ordinary civil lawsuits and hence more expensive to prosecute and defend. If professional rules forbid lawyers to charge speculative or contingent fees (that is, 'no win, no pay' or a fee amount linked to the amount obtained by plaintiffs) there may be few class members who can afford to hire lawyers. But even where professional rules permit speculative fees, there may be few lawyers who can assume the risk of having to cover their own expenses if defendants prevail. In some jurisdictions, legal aid or legal expenses insurance may help parties overcome these financial obstacles. In still others, third-party litigation financers help pay for the litigation in exchange for a share of any monetary remedies.

Substantive and procedural rules that apply to all litigation, class and non-class alike, also determine the attractiveness of bringing class actions. If pleading standards are very strict or evidence hard to obtain, the risk-benefit calculus for parties and lawyers considering bringing class actions will be more negative than if pleading standards are relatively relaxed and document discovery readily available. If the expected value of damages is large-for example, because of statutory treble damages, compounded statutory interest rules or the availability of exemplary or punitive damages - the risk-benefit calculus will be more positive. In the US, arbitration clauses agreed to prior to a dispute arising (for example, in consumer contracts) frequently forbid any form of collective dispute resolution.

No jurisdiction consistently reports the number of class actions filed in its courts annually or the distribution of class action lawsuits by the substantive type of claim. The available evidence suggests that class actions account for a small percentage of all civil lawsuits in the jurisdictions that permit them. In many jurisdictions, there have been just a few class action lawsuits filed to date, perhaps as a result of the obstacles to successful class litigation identified above. In the US, thousands of complaints seeking class certification have been filed in recent decades but fragmentary evidence suggests that only a small fraction of these move forward in the form of class actions (Hensler, forthcoming).

\section{CLASS ACTION CONTROVERSIES}

In virtually every jurisdiction in which a class action procedure has been formally proposed, there has been vigorous controversy about the virtues and vices of class actions. And in many jurisdictions that have adopted class actions, controversies over rules and practices persist long after 
their adoption. The intensity and nature of controversy over class actions vary within and among jurisdictions, reflecting national politics and temporal circumstances.

Debates over the adoption of class actions implicate many different beliefs and values. Historical commitments to individual dispute resolution lead to skepticism about the consequences of aggregating claims whatever the approach. Does treating claims en masse lead to more efficient dispute resolution, or does it simply introduce new sources of litigation expense and delay? If aggregation does reduce the cost of claiming, will it encourage frivolous claims, needlessly increasing the burden on court resources and imposing an inappropriate financial burden on defendants that will ultimately be passed on to consumers? Conversely, does aggregation open the courthouse to parties with legitimate claims that they cannot afford to litigate individually, and help ensure that defendants properly internalize the external impact of their behaviorthat is, the costs they impose on others-when making decisions?

For those who are open to considering aggregating claims under some circumstances, representative class actions raise further questions. How can class members' interests in substantive and procedural due process be assured when they are represented by just one or a few individuals or an association that the class members played no role in selecting? How can defendants' interests be protected when they face a mass of claimants, rather than individuals? How should courts deal with conflicts of interest that may arise among class members? Is it possible to fashion rules and practices that minimize the principal-agent problems that arise when an attorney represents a large group of claimants, none of whom can effectively monitor the lawyer's behavior? Are there holistic answers to these questions about representative litigation, or do the answers differ, depending on the type of substantive claim, suggesting that representative procedures might be appropriate in some circumstances, but not others? Finally, are the issues presented by representative class actions unique to the representative device or are they inherent to all aggregated procedures?

In most jurisdictions, these controversies have proceeded without reference to empirical evidence. The absence of empirical data to test assertions of critics and proponents of class actions is not unique to this debate; in most jurisdictions, collecting and analyzing empirical data to support policy making regarding civil litigation is a relatively new phenomenon. In the absence of such data, claims regarding the frequency of class actions, the ratio of meritorious to non-meritorious suits, and the outcomes of class actions and other collective procedures have not been subject to testing. 
There is also a lack of qualitative evidence about the circumstances that give rise to class actions and other forms of mass litigation, the people and organizations that play a role in shaping litigation, the ways in which formal law and informal practices influence legal strategy and the variety of ways in which litigation is resolved. When critics and supporters of class actions refer to actual cases, they often exaggerate their apparent good and bad points, and rarely discuss the context in which the cases arose: the events leading up to the litigation and the events that may have swirled around it and determined its progress and outcomes. Advocates' stories about lawsuits exaggerate either their (seemingly) positive or (seemingly) negative aspects, erasing complexities that might make judgments about the lawsuits' ultimate value more difficult to reach or more ambivalent. The lack of qualitative data leads to debate that focuses on high theory and ignores the social reality on the ground - the 'law on the books' rather than the 'law in action'. Without such data, policy makers run the risk of making decisions that seem wise from a theoretical perspective but are likely to produce unanticipated consequences when implemented in the real world.

\section{FILLING THE QUALITATIVE EMPIRICAL GAP}

The globalization of class actions and other collective litigation procedures has created an opportunity to learn more about how class actions operate on the ground in different legal regimes, with different legal cultures, rules and practices, and in different political contexts. This book is a first step in that direction. It is the product of a global collaboration that brought together 14 scholars from different parts of the world to conduct qualitative research on recent class or mass litigation in their own or another country.

The method the collaborators selected for their research is the method of choice for qualitative social research. Known as the 'case study' method, it has deep roots in sociological inquiry, but has also been adopted by historians, political scientists and management analysts. It has been used by scholars to investigate the evolution of international crises, the adoption of economic and social policies, and the implementation of business decisions (George \& Bennett, 2005; Yin, 2013). In recent years, it has also been used to investigate civil litigation (Green, 1996; Hensler et al., 2000; Schuck, 1987; Sobol, 1991). The approach is animated by the belief that understanding social phenomena requires intensive investigation of examples of the phenomenon (the 'cases') in the context in which they occur. Sometimes the cases are nations or local communities; 
sometimes they are policies or programs. In research on litigation, the cases are frequently legal disputes or lawsuits.

The case study method relies heavily on close reading of documentary evidence and on interviews with key informants. For this reason, case study research projects almost always investigate only a small number of cases. The representative sampling techniques that are common to large-scale data collection are inapposite to such 'small-N' studies. As a result, both the selection of cases for investigation and the selection of interviewees is purposive rather than random. Because each interviewee is likely to have a different perspective on the process under investigation, the researcher uses a semi-structured interview protocol rather than a standardized questionnaire to guide the interview. Depending on the nature of the questions asked, some of the data collected may be quantitative, but most will be qualitative. The product of the case study approach is a 'thick description' of what happened and why, including the roles different actors played in the program or process under investigation. Over the past several decades, comparative legal scholars have made extensive use of the case study method.

In this project, the case studies for investigation were large-scale litigations that were resolved in class actions, group litigation or aggregated procedures. Each of the project collaborators selected one or more lawsuits (or a related 'family' of lawsuits) that he or she thought would provide insights into the inception, evolution and resolution of mass litigation within that jurisdiction's contemporary legal regime. The substantive legal claims underlying the litigation included employment wage claims, property damage claims arising from catastrophic accidents and environmental contamination, consumer protection, shareholder and other investment claims, and civil rights claims (Table 1.2). This diversity of substantive claims was dictated primarily by differences in the law that permitted or facilitated certain types of claims but not others in the chosen jurisdictions, and secondarily by the researchers' individual interests and expertise and their access to informants. Despite the lack of standardization regarding case selection, securities (shareholder) claims dominated.

At the start of the project, the collaborators agreed on a common interview protocol. The interviews covered the factual circumstances that gave rise to the litigation; the relevant substantive and procedural law; key court decisions; litigation strategy; the roles of judges, parties, legal representatives of parties and civil society; claim characteristics; legal outcomes including damages (if any); and litigation financing. Because, in 
Table 1.2 Type oflegal claims investigated, by jurisdiction

\begin{tabular}{lcl}
\hline Country & $\begin{array}{l}\text { Number of } \\
\text { cases }\end{array}$ & Type of claims \\
\hline Australia & 2 & Securities \\
Belgium & 1 & Securities \\
Brazil & 1 & Consumer \\
Canada & 2 & Securities \& civil rights \\
Chile & 2 & Consumer \\
England & 1 & Catastrophic property damage \\
Germany & 1 & Securities \\
Israel & 1 & Securities \\
Netherlands & 2 & Securities \& insurance \\
Taiwan & 2 & Employment \& securities \\
United States & 4 & Product defect, catastrophic \\
& & property damage, environmental \\
& & contamination \& securities \\
\hline
\end{tabular}

many jurisdictions, the collective litigation procedures used were relatively new, the interviews also covered respondents' views of how the procedures' characteristics affected the litigation and its outcomes. All of the interviews were conducted on a confidential basis, although some interviewees volunteered that they would be pleased to be identified. In addition to interviews, the researchers drew on court documents and media reports of the litigation.

Each of the jurisdictions in which the research took place has a different structure for addressing mass claims. Table 1.3 summarizes the characteristics of the procedures that were in place at the time of the case study research. Australia, Canada and the US have similar (but not identical) class action procedures and each has used the class action procedure for at least a decade. Israel's more recently adopted class action procedure resembles these in many respects. Brazil and Chile's class action regimes rely more on public prosecution than the regimes in the first three countries. Taiwan's class action regime provides for class actions prosecuted by associations and, in securities cases, a quasi-public agency. The Netherlands has two class action regimes, one that permits a class to litigate, with remedies limited to declaratory or injunctive relief, 


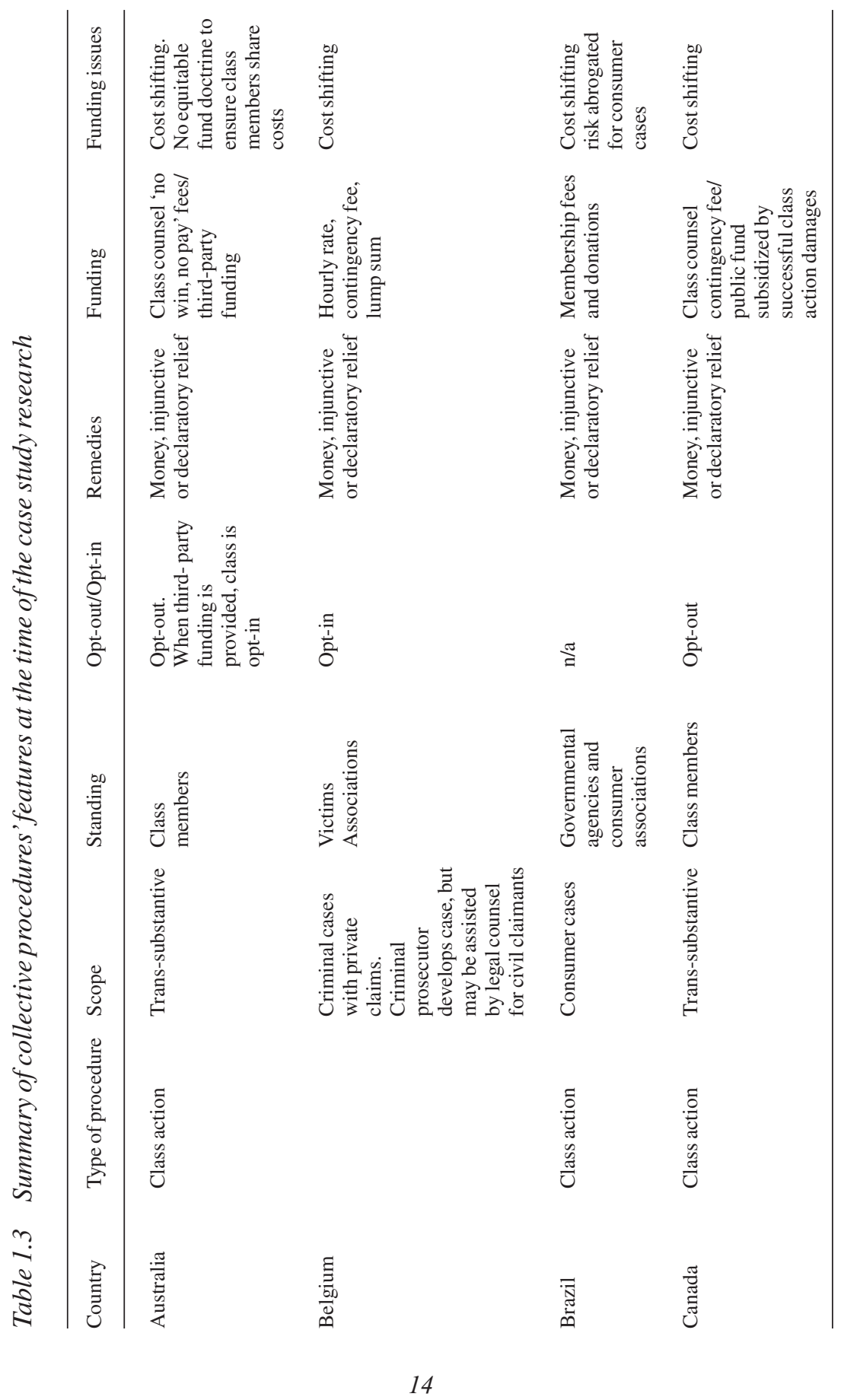




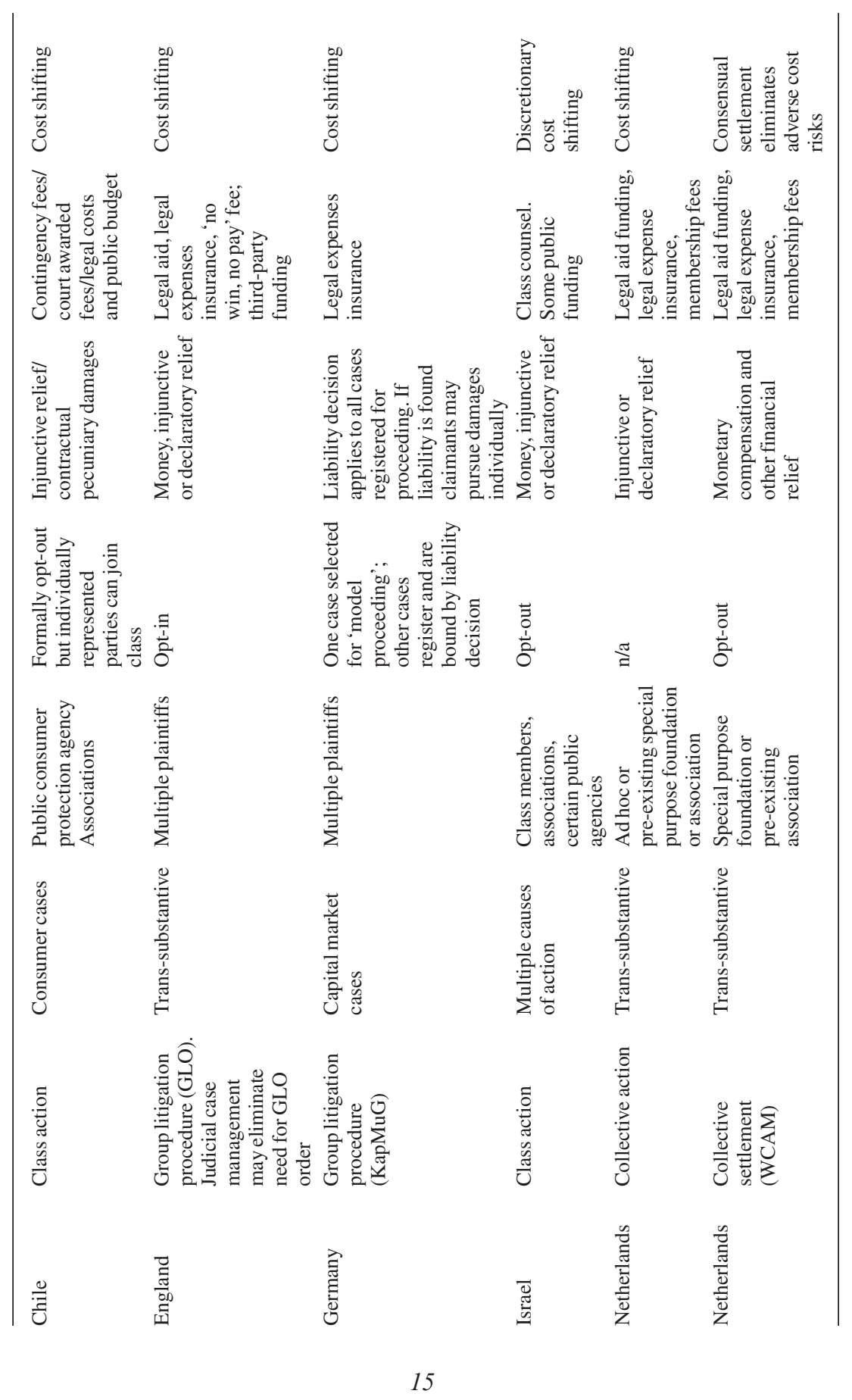




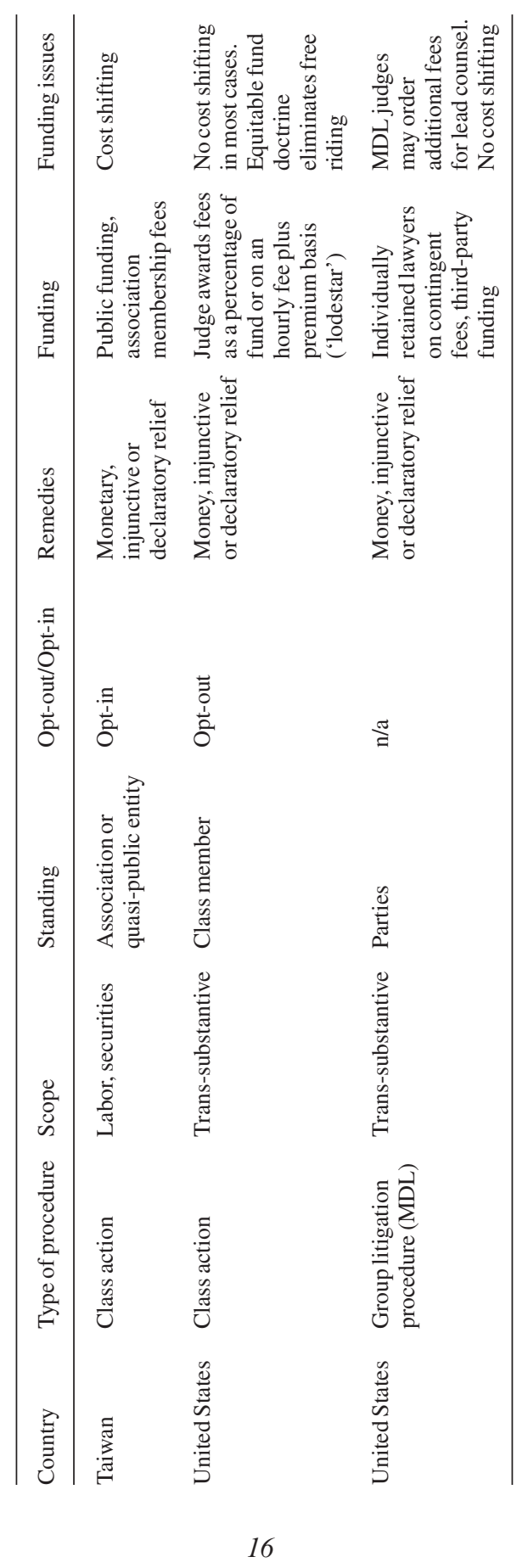


and one that permits class treatment of a negotiated settlement for money damages, with judicial approval. England, Germany and the US all have formal group litigation procedures. In the US, the group litigation procedure is sometimes used in conjunction with a class action. England had not adopted a class action procedure at the time of the study and, over time, judicial case management had come to be regarded as preferable to the formal group litigation procedure that was adopted in the 1990s. Germany has adopted a formal group litigation procedure for investor claims; its judges are said to be uncomfortable engaging in the close judicial case management that is characteristic of US and English judges. Belgium had not adopted a class action procedure at the time of the study; there, civil claims proceeded as 'piggy back' additions to criminal proceedings.

The case studies were conducted between 2010 and 2015. As the research progressed, the collaborators shared their preliminary observations in writing and in person. Early in the process, all were struck by the extent to which certain themes emerged among the cases, despite differences in substantive law, procedural rules, legal regime and national politics. In all of the cases the collaborators investigated, cultural factors played an important role in encouraging litigation and shaping the litigation process and outcomes. 'Culture' has been variously defined by social scientists but generally comprises the ideas, norms and values that are transmitted to and shape the behavior of members of a particular society at a particular time. In the case of litigation, these ideas, norms and values were transmitted by many actors and institutions but particularly by mass media, which often drove litigation forward and led to the delivery of compensation to self-perceived victims, even when the formal law did not require such compensation.

A second theme cutting across all cases was the importance of legal financing rules. The aphorism 'money makes the world go round' applies to litigation worldwide. The availability of legal financing enables litigation and in its absence, litigation generally fails. Although the importance of financing may seem obvious, it is often neglected in statutory decision-making and rule-making pertaining to class actions and other collective litigation procedures. Countries that adopt new collective litigation procedures rarely adopt different legal financing rules to accommodate the new forms of litigation. In some instances, this has stymied use of the new procedures. However, in others, the advent of collective litigation has incentivized new forms of legal financing, an example of how legal procedural developments can impact other dimensions of a legal regime. 
A third theme was the importance of public legal actors to the development and outcomes of what is ostensibly private legal action. In the cases the researcher investigated, public actors sometimes facilitated and sometimes hindered private litigation. Sometimes the private litigation was caught up in larger political debates of the day. The publicprivate law distinction that is so central to legal theory and has been at the core of the debate over class actions in many jurisdictions was less easy to discern 'on the ground'.

As they proceeded with their research, the collaborators attempted to test these cross-cutting observations against their data. By holding up their individual case study research to these over-arching themes, the researchers hoped that the ultimate product of the project would be more than simply a collection of individual case studies. Ultimately the themes became the organizing structure of this book.

\section{ORGANIZATION OF THE BOOK}

Most of the book is devoted to the case studies. With one exception, each case study reports on litigation within a single country; the exception is a chapter reporting on a transnational litigation that took place both in the US and the Netherlands. Some chapters report on a single case and some on two cases.

Rather than organizing the chapters by geographic locale or by type of legal regime or some other legal variable, the book groups the chapters by theme. Part II focuses on cultural factors that shape collective litigation; Part III on the economic enablers of collective litigation; and Part IV on the public dimension of private collective litigation. Each of these Parts begins with a chapter that introduces the theme, summarizes the case study results in that Part and analyzes how those cases illustrate the theme. Part V synthesizes the descriptive data and analysis in the preceding chapters and discusses their implications for public policymaking and scholarship.

Readers interested in the 'big picture' of collective litigation might read only the introductory chapters in each Part and the conclusion, and perhaps dip into one or two case study chapters to get a better sense of the materials the authors of these chapters drew upon. Readers interested in learning more about a particular jurisdiction or a particular type of litigation might focus on those chapters most relevant to their interests. Law faculty who assign the book for classes on private law, complex 
litigation or comparative law might wish to assign different chapters to different students as a basis for in-class discussion on comparative procedure.

The authors, of course, hope that you will read the entire volume.

\section{REFERENCES}

Frank Dobbins, Beth Simmons \& Geoffrey Garrett, The Global Diffusion of Public Policies: Social Construction, Coercion, Competition, or Learning? (2007) 33 Annual Review of Sociology 449

Kenneth Feinberg, Who Gets What? Fair Compensation After Tragedy and Financial Upheaval (Perseus Books 2012)

Alexander George \& Andrew Bennett, Case Studies and Theory Development in the Social Sciences (MIT Press 2005)

Michele Graziadei, Comparative Law as the Study of Legal Transplants, in Mathias Reimann \& Reinhard Zimmermann (eds.), The Oxford Handbook of Comparative Law (Oxford University Press 2006)

Michael Green, Bendectin and Birth Defects: The Challenge of Mass Toxic Substances Litigation (University of Pennsylvania Press 1996)

Deborah Hensler et al., Class Action Dilemmas: Pursuing Public Goals for Private Gain (RAND 2002)

Deborah Hensler, The Socio-Economics of Mass Torts: What We Know, Don't Know and Should Know, in Jennifer Arlen (ed.), Research Handbook on the Economics of Torts (Edward Elgar 2013)

Deborah Hensler, Justice for the Masses? Aggregate Litigation and Its Alternatives, in Judith Resnik \& Linda Greenhouse (eds.), The Invention of Courts, Daedalus 143:3, Summer 2014 (MIT Press)

Deborah Hensler, Can Private Class Actions Enforce Marketplace Regulations? Do They? Should They?, in Francesca Bignami \& David Waring (eds.), Comparative Law and Regulation: National, International and Transnational Perspectives (Edward Elgar forthcoming)

Christopher Hodges, Multi-Party Actions (Oxford University Press 2001)

Christopher Hodges, Stefan Vogenauer \& Magdalena Tulibacka (eds.), The Costs and Funding of Civil Litigation: A Comparative Approach (Hart 2010)

Peter Schuck, Agent Orange on Trial: Mass Toxic Disasters in the Courts (Belknap Press 1987)

Richard Sobol, Bending the Law: The Story of the Dalkon Shield Bankruptcy (University of Chicago Press 1991)

Alan Watson, Legal Transplants: An Approach to Comparative Law (University Press of Virginia 1974)

Robert Yin, Case Study Research: Design and Method, 5th edition (Sage 2013) 
Deborah R. Hensler - 9781783470440 Downloaded from PubFactory at 04/26/2023 09:38:21AM via free access 